\title{
The Association of Pulse Pressure and Pre-Metabolic Syndrome in Korean Middle Aged Men
}

\author{
Kyung-A Shin \\ Department of Clinical Laboratory Science, Shinsung University, Chungnam 31801, Korea
}

\begin{abstract}
Pulse pressure is an independent risk factor for cardiovascular disease. The aim of the present study was to assess the association between pulse pressure and metabolic syndrome in Korean men. The study subjects were 8,439 adults aged 40 to 64 years, who underwent health screening examination from January 2012 to December 2014 at the Health Promotion Center of one hospital in Gyeonggi-do for general health check-up. They include the metabolic syndrome absent group (Absent, $n=3,078$ ), the pre-metabolic syndrome group (Pre-MetS, $n=4,242$ ) and the metabolic syndrome group (MetS, $\mathrm{n}=1,119)$. Progressive increase in pulse pressure was demonstrated for increasing components of the metabolic syndrome $(P<0.001)$. The pulse pressure according to the degree of the metabolic syndrome was higher in the pre-MetS and MetS groups compared to the Absent group $(P<0.001)$. Systolic and diastolic blood pressure, total cholesterol, triglyceride, fasting glucose, and abdominal obesity positively correlated with pulse pressure $(P<0.001)$.
\end{abstract}

Key Words: Pulse pressure, Metabolic syndrome, Pre-Metabolic syndrome

\section{서 론}

맥압(pulse pressure, PP)은 수축기 혈압과 이완기 혈압의 차이를 나타내며, 기초적인 건강평가를 위해 쉽게 측정 가 능한 지표이다(Kwon et al., 2017). 맥압이 높을수록 울혈 성 심부전이나 심방세동과 같은 심장관련 질환을 동반하 게 되며, 동맥경화증의 표지자로 활용되고 있다(Chae et al., 1999; Haider et al., 2003; Cremer et al., 2015). 따라서 높 은 맥압은 심혈관질환의 독립적인 위험인자로 인식된다 (Franklin et al., 1999).

대사증후군은 전세계적으로 급속한 증가를 보이고 있으 며, 복부비만, 혈압 상승, 고혈당 및 이상지질혈증과 같은 심혈관질환 위험요인의 군집현상을 특징으로 한다(Grundy et al., 2005). 대사증후군은 연령이 증가함에 따라 증가하
는 경향을 보이며(Hildrum et al., 2007), 우리나라 2007년 국민건강영양조사에서도 40 대 이상 중년층의 대사증후군 유병률은 $35.2 \%$ 로, 연령 증가와 비례하여 대사증후군 유 병률의 증가를 보였다(Moon and Kong, 2010). 대사증후군 과 대사증후군 위험요인은 동맥두께의 증가와 동맥경화 및 동맥 경직도(arterial stiffness)를 촉진시키는 핵심역할 을 하는 것으로 알려져 있다(Benetos et al., 1998; Scuteri et al., 2011). 대사증후군은 노인뿐 아니라 중년층에서도 중 요한 건강문제 중 하나인데, 이는 대사증후군이 진행되어 심혈관질환을 유발할 수 있기 때문이다(Kwon et al., 2017). 맥압과 대사증후군간의 연관성에 대해서 고혈압 환자를 대상으로 맥압의 증가는 큰 동맥에 경화가 증가하였음 을 반영하며, 대사증후군과 관련된 심혈관 위험의 증가를 설명하는데 기여할 수 있다고 보고된다(Mulè et al., 2007; Protogerou et al., 2007). 또한 Kwon 등(2017)은 한국 노인

*Received: March 12, 2017 / Revised: April 3, 2017 / Accepted: May 21, 2017

${ }^{\dagger}$ Corresponding author: Kyung-A Shin. Department of Clinical Laboratory Science, Shinsung University, 1 Daehak-Ro, Dangin-Si, Chungnam 31801, Korea. Tel: +82-41-350-1408, Fax:+82-41-350-1355, e-mail: mobitz2@shinsung.ac.kr

(C) The Korean Society for Biomedical Laboratory Sciences. All rights reserved.

(C) This is an Open Access article distributed under the terms of the Creative Commons Attribution Non-Commercial License (http://creativecommons.org/licenses/by-nc/3.0/) which permits unrestricted non-commercial use, distribution, and reproduction in any medium, provided the original work is properly cited. 
을 대상으로 대사증후군 발병 증가와 맥압은 양의 상관관 계에 있으며, 대사증후군 위험요인이 없는 군보다 대사증 후군 진단군에서 맥압의 증가가 더 두드러짐을 보고하였 다. 맥압과 대사증후군간의 관련성은 인슐린 저항성과 만 성 저강도 염증(chronic low grade inflammation)에 의해 매 개되는 것으로 추측된다(Kwon et al., 2017). 그러나 이러한 연구들은 고혈압 환자나 일반 노인에서 제한적으로 맥압 과 대사증후군간의 연관성을 평가하고 있다. 특히 맥압은 노인들의 관상동맥 심장질환을 예측하는 인자로 제시되고 는 있으나(Franklin et al., 1999), 본 연구에서는 한국 중년남 성을 대상으로 맥압과 대사증후군간의 연관성을 평가하고 자 하였다. 또한 대사증후군 위험요인이 없는군과 비교해 대사증후군 진단군과 대사증후군으로 진행되는 전단계인 $1 \sim 2$ 개의 위험요인을 가진 대사증후군 전단계군에서의 맥 압 차이를 알아보고자 하였다.

\section{재료 및 방법}

\section{연구 대상자 및 대사증후군 진단}

본 연구 대상자는 2012년 1월부터 2014년 12월까지 경 기지역 $J$ 종합병원의 건강검진센터를 방문하여 건강검진 을 받은 40세 이상 64세 이하의 중년남성을 대상으로 하 였다. 전체 대상자 총 10,560 명 중 고혈압 약제를 복용 중 인 사람과 결측치를 포함하는 2,121 명을 제외한 최종 연 구 대상자는 8,439 명이었다. 복용하는 약물에 대한 조사 는 자기기입식 문진표를 통해 이루어졌으며, 본 연구는 경기지역 $J$ 종합병원의 기관생명윤리위원회 승인을 받아 시행되었다(IRB No: D-1206-010-5941). 대사증후군 진단은 AHA/NHLBI (American Heart Association/National Heart, Lung, and Blood Institute, 2005)의 기준에 따라 복부비만, 혈압 상승, 혈당 상승, 중성지방 상승, $\mathrm{HDL}$-콜레스테롤 감 소의 5 가지 위험요인 중 3 가지 이상 해당하는 경우 대사 증후군 진단군(MetS; metabolic syndrome, $\mathrm{n}=1,119)$ 으로 판 정하였다(Grundy et al., 2005). 또한 1 2개의 위험요인을 가진 대사증후군 전단계군(Pre-MetS; pre-metabolic syndrome, $\mathrm{n}=4,242)$, 대사증후군 위험요인이 없는 군(Absent, $\mathrm{n}=3,078)$ 으로 분류하였다. 대사증후군 진단의 세부 항목으로 혈압 상승은 수축기 혈압 $\geq 130 \mathrm{mmHg}$ 또는 이완기 혈압 $\geq 85$ $\mathrm{mmHg}$ 인 경우, 혈당 상승은 공복혈당 $\geq 100 \mathrm{mg} / \mathrm{dL}$ 인 경우 였다. 중성지방 상승은 혈중 중성지방 $\geq 150 \mathrm{mg} / \mathrm{dL}, \mathrm{HDL}$ (high density lipoprotein)-콜레스테롤 감소는 혈중 HDL-콜 레스테롤이 $<40 \mathrm{mg} / \mathrm{dL}$ 로 하였다. 복부비만은 $\mathrm{AHA} / \mathrm{NHLBI}$
기준으로 남성 허리둘레 $\geq 102 \mathrm{~cm}$ 으로 정의하고 있으나, 동양인의 복부비만 기준에 적합하지 않아 아시아-태평양 지역의 기준(Asia-Pacific Criteria, APC)에 따라 남성 $\geq 90$ $\mathrm{cm}$ 을 복부비만 기준으로 적용하였다(WHO, 2000).

\section{신체계측 및 맥압측정}

신장과 체중은 DS-103M (Jenix, Seoul, Korea) 자동 신체 계측기를 이용하여 측정하였으며, 체질량지수(body mass index, BMI)는 몸무게 $(\mathrm{kg}) / \exists\left(\exists \mid\left(\mathrm{m}^{2}\right)\right.$ 의 공식으로 추정하였다. 허리둘레는 양 발을 $25 \sim 30 \mathrm{~cm}$ 정도 벌리고 숨을 내쉰 상 태에서 갈비벼 가장 아래위치와 골반의 가장 높은 위치의 중간부위를 측정하였으며, 엉덩이 둘레는 엉덩이의 가장 돌출된 부분을 지나 수평이 되도록 하여 줄자로 측정하였 다. 수축기와 이완기 혈압은 10 분 이상 안정을 취한 후 앉 은 자세에서 수은 혈압계로 측정하였으며, 2 분 이상 휴식 후 2회 반복 측정하여 평균값을 결과로 사용하였다. 또한 맥압은 최고 혈압과 최저 혈압의 차이를 나타내며, 수축 기 혈압에서 이완기 혈압을 뺀 수치로 정의하였다(Kwon et al., 2017).

\section{혈액검사}

혈액검사는 8시간 이상 금식한 후 전주정맥(antecubital vein)에서 채혈하였으며, TBA-200FR NEO (Toshiba, Tokyo, Japan) 생화학 자동분석기로 총콜레스테롤, HDL-콜레스테 롤, $\mathrm{LDL}$-콜레스테롤, 중성지방, 공복혈당, 고감도 $\mathrm{C}$-반응 단백질(high sensitivity C-reactive protein, hs-CRP), 요산을 측정하였다. 당화혈색소(hemoglobin $\mathrm{A} 1 \mathrm{c}, \mathrm{HbAlc}$ )는 전혈 검체로 Variant II (Bio Rad, $\mathrm{CA}, \mathrm{USA}$ ) 장비로 전용시약을 이용하여, 고성능액체크로마토그래피법(high performance liquid chromatography, HPLC)의 원리로 측정하였다. 인슐린 은 Modular Analytics E170 (Roche, Mannheim, Germany) 장 비로 전용시약을 이용하여, 전기화학발광면역분석법(electrochemiluminescence immunoassay, ECLIA)으로 검사하였다. HOMA-IR (homeostasis model assessment-insulin resistance) 은 인슐린 저항성을 평가하는 지표로, 공복혈당과 인슐린 농도를 이용하여 [공복시 인슐린 $(\mu \mathrm{IU} / \mathrm{mL}) \times$ 공복시 혈당 $(\mathrm{mg} / \mathrm{dL})] / 405$ 의 계산식으로 산출하였다(Moon et al., 2010).

\section{자료처리방법}

본 연구에서 통계학적 분석은 SPSS Windows 21.0 (IBM, Armonk, USA) 통계 프로그램을 이용하였으며, 대사증후 군 위험요인이 없는군, 대사증후군 전단계군, 대사증후군 
진단군간의 맥압 차이를 알아보기 위해 일원변량분석(one way ANOVA)을 실시하였으며, 차이가 있는 경우 사후검 정은 Scheffé 검정법을 적용하였다. 또한 집단간 성별 및 혈압 상승, 혈당 상승, 중성지방 상승, $\mathrm{HDL}$-콜레스테롤 감 소의 5 가지 대사증후군 위험요인 유병률의 차이를 알아 보기 위해 카이제곱 검정(chi-square test)을 실시하였다. 대 사증후군 각각의 위험요인의 유무에 따른 맥압 차이를 비 교하기 위해 독립표본 $t$ 검정(independent $t$-test)을 시행하 였으며, 맥압과 대사증후군 위험요인간의 관련성을 파악 하기 위해 Pearson의 상관분석을 실시하였다. 본 연구의 통계학적 유의수준은 $P<0.05$ 로 설정하였다.

\section{결 과}

대사증후군 정도에 따른 대상자의 의학적 특성 및 맥압 차이

본 연구에 참여한 대상자를 대사증후군 위험요인이 없 는군(Absent), 대사증후군 전단계군(Pre-MetS), 대사증후군 진단군(MetS)으로 분류하여 세 집단의 의학적 특성 및 맥 압의 차이를 비교한 결과는 Table 1 과 같다. 연령은 집단 간 차이를 보였으며, Absent군보다 Pre-MetS군과 MetS군의 연령이 높았으며, Pre-MetS군보다 MetS군의 연령이 높았

Table 1. Clinical and biochemical characteristics according to the metabolic syndrome status

\begin{tabular}{|c|c|c|c|c|}
\hline Variable & $\begin{array}{c}\text { Absent } \\
(\mathrm{N}=3,078)\end{array}$ & $\begin{array}{c}\text { Pre-MetS } \\
(\mathrm{N}=4,242)\end{array}$ & $\begin{array}{c}\text { MetS } \\
(\mathrm{N}=1,119)\end{array}$ & $P$-value \\
\hline Age (yr) & $48.30 \pm 6.24$ & $49.10 \pm 6.42^{*}$ & $50.04 \pm 6.72^{* \dagger}$ & $<0.001$ \\
\hline Height (cm) & $170.41 \pm 5.87$ & $170.57 \pm 5.88$ & $171.14 \pm 6.05^{* \dagger}$ & 0.002 \\
\hline Weight (kg) & $67.77 \pm 7.57$ & $73.00 \pm 8.90^{*}$ & $80.38 \pm 10.20^{* \dagger}$ & $<0.001$ \\
\hline BMI $\left(\mathrm{kg} / \mathrm{m}^{2}\right)$ & $23.41 \pm 4.69$ & $25.20 \pm 6.18^{*}$ & $27.41 \pm 2.85^{* \dagger}$ & $<0.001$ \\
\hline Waist circumference (cm) & $79.97 \pm 5.53$ & $85.07 \pm 6.53^{*}$ & $91.89 \pm 6.80^{* \dagger}$ & $<0.001$ \\
\hline Hip circumference (cm) & $92.56 \pm 4.36$ & $95.23 \pm 4.98^{*}$ & $98.86 \pm 5.59^{* \dagger}$ & $<0.001$ \\
\hline Systolic blood pressure (mmHg) & $107.43 \pm 9.21$ & $114.77 \pm 13.24^{*}$ & $123.67 \pm 14.79^{* \dagger}$ & $<0.001$ \\
\hline Diastolic blood pressure (mmHg) & $69.23 \pm 7.60$ & $74.60 \pm 10.13^{*}$ & $80.91 \pm 10.73^{* \dagger}$ & $<0.001$ \\
\hline Total cholesterol (mg/dL) & $191.97 \pm 30.76$ & $201.06 \pm 34.96^{*}$ & $200.65 \pm 36.53^{*}$ & $<0.001$ \\
\hline HDL-cholesterol (mg/dL) & $56.89 \pm 11.14$ & $50.10 \pm 11.26^{*}$ & $44.38 \pm 10.42^{* \dagger}$ & $<0.001$ \\
\hline LDL-cholesterol (mg/dL) & $120.13 \pm 28.31$ & $126.74 \pm 31.31^{*}$ & $123.22 \pm 33.12^{* \dagger}$ & $<0.001$ \\
\hline Triglyceride (mg/dL) & $91.41 \pm 30.00$ & $167.92 \pm 96.77^{*}$ & $240.51 \pm 111.08^{* \dagger}$ & $<0.001$ \\
\hline Fasting glucose (mg/dL) & $85.56 \pm 7.35$ & $96.17 \pm 22.31^{*}$ & $112.85 \pm 32.70^{* \dagger}$ & $<0.001$ \\
\hline hs-CRP (mg/dL) & $0.15 \pm 0.57$ & $0.17 \pm 0.43$ & $0.20 \pm 0.50^{* \dagger}$ & 0.012 \\
\hline $\mathrm{HbA1c}(\%)$ & $5.45 \pm 0.31$ & $5.77 \pm 0.84^{*}$ & $6.30 \pm 1.17^{* \dagger}$ & $<0.001$ \\
\hline Insulin $(\mu \mathrm{U} / \mathrm{mL})$ & $3.43 \pm 2.00$ & $5.30 \pm 2.61^{*}$ & $7.47 \pm 3.58^{* \dagger}$ & $<0.001$ \\
\hline HOMA-IR & $0.13 \pm 0.34$ & $0.27 \pm 0.62^{*}$ & $0.46 \pm 1.01^{* \dagger}$ & $<0.001$ \\
\hline Uric acid (mg/dL) & $5.75 \pm 1.15$ & $6.04 \pm 1.26^{*}$ & $6.23 \pm 1.42^{* \dagger}$ & $<0.001$ \\
\hline \multicolumn{5}{|l|}{ Metabolic syndrome components } \\
\hline High blood pressure $e^{\S}$ & 0 & $987(23.3)$ & $623(55.7)$ & $<0.001$ \\
\hline Low HDL-cholesterol $^{\S}$ & 0 & $637(15.0)$ & $489(43.7)$ & $<0.001$ \\
\hline High fasting glucose $\mathrm{e}^{\S}$ & 0 & $1,102(26.0)$ & $736(65.8)$ & $<0.001$ \\
\hline Abdominal obesity ${ }^{\S}$ & 0 & $996(23.5)$ & $803(71.8)$ & $<0.001$ \\
\hline High triglyceride $^{\S}$ & 0 & $2,191(51.7)$ & $996(89.0)$ & $<0.001$ \\
\hline
\end{tabular}

Calculated by one way ANOVA and scheffé test.

Values are presented as mean $\pm \mathrm{SD}$.

$\S$; Calculated by $\chi^{2}$-test. Data are presented as number (\%).

Abbreviations: MetS, metabolic syndrome; BMI, body mass index; HDL, high density lipoprotein; LDL, low density lipoprotein; hs-CRP, high sensitivity C-reactive protein; HbAlc, hemoglobin A1c.

; Significantly different from Normal at $P<0.05$, ${ }^{\dagger}$; Significantly different from Pre-MetS at $P<0.05$. 


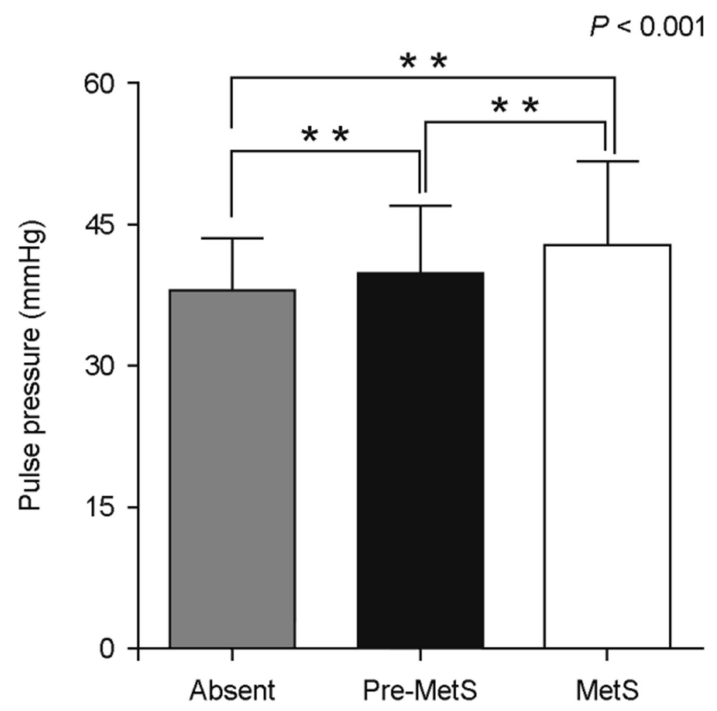

Fig. 1. Mean pulse pressure level according to the metabolic syndrome status. The Pre-MetS and MetS increase significantly by the pulse pressure level at $P<0.001$. Absent; $37.97 \pm 5.55$, Pre-

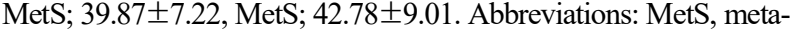
bolic syndrome.

다 $(P<0.001)$. 인체측정학적 변인 중 체중, 체질량지수, 허 리둘레, 엉덩이 둘레는 Absent군보다 Pre-MetS군과 MetS 군에서 크게 나타났으며, Pre-MetS군보다 MetS군이 큰 것으로 나타났다(각각 $P<0.001$ ). 신장은 Absent군과 Pre$\mathrm{MetS}$ 군보다 MetS군이 큰 것으로 나타났다 $(P=0.002)$. 생 화학적 변인 중 $\mathrm{LDL}-$ 콜레스테롤, 중성지방, 공복혈당, $\mathrm{HbA1c}$, 인슐린, HOMA-IR, 요산은 Absent군보다 Pre-MetS 군과 MetS군에서 높았으며, Pre-MetS군보다 MetS군이 높 았다(각각 $P<0.001)$. 그러나 $\mathrm{HDL}$-콜레스테롤은 Absent군 보다 Pre-MetS군과 MetS군에서 낮았으며, Pre-MetS군보다 $\operatorname{MetS}$ 군이 낮았다 $(P<0.001)$, 총콜레스테롤은 Absent군보 다 Pre-MetS군과 MetS군이 높았으며 $(P<0.001), \mathrm{hs-CRP는}$ Absent군과 Pre-MetS군보다 MetS군에서 높았다 $(P=0.012)$. 혈역학적 변인으로 수축기와 이완기 혈압은 Absent군보 다 Pre-MetS군과 MetS군에서 높았으며, Pre-MetS군보다 MetS군에서 높았다(각각 $P<0.001)$. 또한 맥압은 Absent군

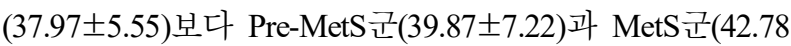
$\pm 9.01)$ 에서 높았으며, Pre-MetS군보다는 MetS군이 높았다 $(P<0.001)$ (Fig. 1). 세 집단간 대사증후군 위험요인별 유병 률의 빈도는 Absent군에서 MetS군으로 진행할수록 점증 적으로 높은 빈도를 보였다(각각 $P<0.001)$.
Table 2. Prevalence of patients and pulse pressure according to the increasing number of metabolic syndrome risk factors

\begin{tabular}{lrrr}
\hline \hline $\begin{array}{l}\text { Number of metabolic } \\
\text { syndrome risk factors }\end{array}$ & $\begin{array}{c}\text { Number of } \\
\text { case (\%) } \\
(\mathrm{n}=8,439)\end{array}$ & $\begin{array}{c}\text { Pulse } \\
\text { pressure }\end{array}$ & $P$-value \\
\hline 0 & $3,078(36.5)$ & $37.97 \pm 5.55$ & \\
1 & $2,571(30.5)$ & $39.30 \pm 6.74$ & \\
2 & $1,671(19.8)$ & $40.74 \pm 7.83$ & $<0.001$ \\
3 & $850(10.1)$ & $42.54 \pm 8.93$ & \\
4 & $248(2.9)$ & $43.57 \pm 9.26$ & \\
5 & $21(0.2)$ & $43.09 \pm 9.54$ & \\
\hline Normal & $7,320(86.7)$ & $39.07 \pm 6.64$ & $<0.001$ \\
MetS & $1,119(11.3)$ & $42.78 \pm 9.01$ & \\
\hline
\end{tabular}

Calculated by Independent $t$-test and one way ANOVA.

Values are presented as mean \pm SD.

Abbreviations: MetS, metabolic syndrome

Table 3. Correlation between pulse pressure level and metabolic syndrome risk factors

\begin{tabular}{lcc}
\hline \multirow{2}{*}{ Metabolic syndrome risk factors } & \multicolumn{2}{c}{ Pulse pressure } \\
\cline { 2 - 3 } & $r$ & $P$-value \\
\hline Systolic blood pressure (mmHg) & 0.655 & $<0.001$ \\
Diastolic blood pressure (mmHg) & 0.156 & $<0.001$ \\
Total cholesterol (mg/dL) & 0.040 & $<0.001$ \\
HDL-cholesterol (mg/dL) & 0.018 & 0.095 \\
LDL-cholesterol (mg/dL) & 0.017 & 0.111 \\
Triglyceride (mg/dL) & 0.064 & $<0.001$ \\
Fasting glucose (mg/dL) & 0.099 & $<0.001$ \\
Abdominal obesity & 0.112 & $<0.001$ \\
\hline
\end{tabular}

Calculated by Pearson correlation coefficient.

Abbreviations: HDL, high density lipoprotein; LDL, low density lipoprotein.

\section{대사증후군 위험요인 군집성에 따른 맥압 차이}

대사증후군 위험요인의 이상 소견 수에 따른 맥압의 평 균을 비교해 본 결과, 대사증후군 위험요인의 이상 소견 숫자가 증가할수록 맥압이 유의하게 증가하는 경향을 보 였다 $(P<0.001)$. 또한 대사증후군 유무에 따른 맥압의 차 이를 비교한 결과 정상군(39.07 \pm 6.64$)$ 보다 대사증후군 진

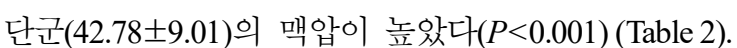

\section{맥압과 대사증후군 위험요인간의 관련성}

맥압과 대사증후군 위험요인간의 상관관계를 나타낸 결 
Table 4. Pulse pressure levels with/without each metabolic syndrome risk factors

\begin{tabular}{lccc}
\hline \hline Metabolic syndrome risk factors & $\begin{array}{c}\text { With metabolic syndrome } \\
\text { risk factor }\end{array}$ & $\begin{array}{c}\text { Without metabolic syndrome } \\
\text { risk factor }\end{array}$ & $P$-value \\
\hline Abdominal obesity & $40.54 \pm 7.71$ & $39.30 \pm 6.91$ & $<0.001$ \\
& $(\mathrm{n}=1,799)$ & $(\mathrm{n}=6,640)$ & $<0.001$ \\
High blood pressure & $45.24 \pm 9.74$ & $38.22 \pm 5.54$ \\
& $(\mathrm{n}=1,610)$ & $(\mathrm{n}=6,829)$ & $<0.001$ \\
High blood glucose & $41.22 \pm 7.96$ & $39.10 \pm 6.78$ & $<0.001$ \\
& $(\mathrm{n}=1,838)$ & $(\mathrm{n}=6,601)$ & $39.29 \pm 6.96$ \\
High triglyceride & $40.01 \pm 7.33$ & $(\mathrm{n}=5,252)$ & $39.59 \pm 7.11$ \\
& $(\mathrm{n}=3,187)$ & $(\mathrm{n}=7,313)$ & 0.431 \\
Low HDL-cholesterol & $39.41 \pm 7.11$ & $(\mathrm{n}=1,126)$ & \\
\hline
\end{tabular}

Calculated by independent $t$-test.

Values are presented as mean \pm SD.

Abbreviations: HDL, high density lipoprotein; LDL, low density lipoprotein.

과, 수축기 $(r=0.655, P<0.001)$ 와 이완기 혈압 $(r=0.156, P<$ $0.001)$, 총콜레스테롤 $(r=0.040, P<0.001)$, 중성지방 $(r=0.064$, $P<0.001)$, 공복혈당 $(r=0.099, P<0.001)$, 복부비만 $(r=0.112$, $P<0.001)$ 은 맥압과 양의 상관관계를 보였으며, 이 중 수 축기 혈압이 가장 높은 상관관계를 보였다(Table 3 ).

\section{대사증후군 각각의 위험요인 유무에 따른 맥압 차이}

대사증후군 각각의 위험요인 유무에 따른 맥압의 평균 을 비교해본 결과, 위험요인이 없는군보다 복부비만, 높은 혈압, 높은 혈당, 고중성지방혈증의 위험요인이 있는 경우 맥압이 높게 나타났다(각각 $P<0.001$ ). 그러나 저 $\mathrm{HDL}-$ 콜 레스테롤증의 위험요인이 있는 경우는 집단간 맥압에 차 이가 없었다(Table 4).

\section{고 찰}

본 연구에서는 한국 중년남성에서 맥압과 대사증후군 간에 관련이 있는지를 조사하였다. 그 결과 대사증후군 위험요인이 증가할수록 비례하여 맥압의 증가를 보였으 며, 대사증후군 진단군뿐만 아니라 대사증후군으로 진행 되는 전단계군에서도 맥압의 증가를 보였다. 또한 대사증 후군 위험요인 중 수축기와 이완기 혈압, 총콜레스테롤, 중성지방, 공복혈당, 복부비만은 맥압과 양의 상관관계를 보였다.

기본적인 건강평가를 위해 쉽게 측정 가능한 맥압은 생 리학적으로 좌심실 구혈률(ventricular ejection), 동맥 경직 도, 반사파(wave reflection)와 같은 혈역학적 요인으로 구
성되기 때문에 동맥 경직도가 증가할수록 맥압이 증가하 는 경향을 보여, 동맥경화 및 죽상경화증의 지표로 활용 된다(Benetos et al., 1998; Lee, 2002; Kwon et al., 2017). 이러 한 맥압은 경동맥 두께(carotid intima-media thickness), 경 동맥 경화증, 좌심실 비대와 관련이 있으며, 뇌졸중, 심근 경색, 심부전 등 심혈관계질환의 간접적 예측인자로 알려 져 있다(Pannier et al., 1989; Finkel and Holbrook, 2000; Choi, 2015). 또한 맥압은 혈관의 노화를 반영하는 지표로 제시 되는데, 건강한 혈관은 탄력이 있어 수축기와 이완기 혈 압을 적절히 조절하지만 나이가 들어감에 따라 혈관은 탄 력을 잃고 경직되면서 수축기 혈압은 상승하고 이완기 혈 압은 저하되어 결국 맥압이 상승하게 된다(Franklin et al., 1999; Gasowski et al., 2002).

이와 관련된 Franklin 등(1999)의 연구에 의하면 맥압이 $10 \mathrm{mmHg}$ 상승하면 관상동맥질환이 $22 \%$ 증가하며, 맥압 이 높을수록 사망률도 증가한다고 보고하였다. 또한 고혈 압 전단계에서 맥압이 $20 \mathrm{mmHg}$ 이상 상승하면 고혈압으 로 진행할 위험이 9배 이상인 것으로 보고된다(Kim et al., 2008). 최근 연구에서 Kwon 등(2017)은 우리나라 국민건 강영양조사 자료를 이용하여 노인에서 맥압과 대사증후 군간에 양의 상관관계가 있음을 보고하였다.

본 연구결과 맥압은 대사증후군 위험요인의 이상 소견 숫자가 증가할수록 비례하여 증가하며, 대사증후군 진단 군과 더불어 대사증후군 전단계군에서도 증가를 보였다. 이 같은 결과는 대사증후군으로 진행하기 전단계에서도 조기 진단과 생활습관의 개선이 요구됨을 의미하는 결과 이다. 맥압은 60 대 이상 노년층에서 심혈관질환의 이환율 
과 사망률의 예측인자로 그 중요성이 강조되지만, 본 연 구결과를 통해 중년남성에서도 혈관 경직도의 간접 지표 인 맥압의 중요성을 간과해서는 안될 것이다. Protogerou 등(2007)은 고혈압 환자를 대상으로 정상군보다 대사증후 군 진단군에서 맥압의 증가가 더 두드러지게 나타남을 보 고하였으며, Mulè 등(2007)도 비-당뇨성 고혈압 환자를 대상으로 대사증후군과 맥압간에 양의 상관관계가 있음을 보고하였다. 그러나 이러한 연구는 고혈압 환자에서 제한 적으로 시행되었고 연령 분포도 다양하여, 건강한 중년남 성에서의 맥압과 대사증후군을 평가하지 못했다. 또 다른 연구에서는 연령과 평균 동맥혈압을 보정한 후에는 맥압 과 대사증후군 구성요소간에 관련성이 없음을 보고하였다 (Mannucci et al., 2007).

맥압과 대사증후군간의 관련성은 인슐린 저항성과 만 성 저강도 염증상태에 의해 매개되는 것으로 추측된다 (Kwon et al., 2017). 특히 대사증후군 및 그 위험요인들은 혈관노화를 촉진시키고 상호작용에 의해 동맥경화를 유 발하는 것으로 알려져 있다(Scuteri et al., 2004; Kwon et al., 2017). 나이가 들어감에 따라 큰 동맥의 콜라겐은 현저하 게 증가되고 엘라스틴 섬유는 파열되어 혈관벽이 더 경화 된다(Wagenseil and Mecham, 2012). 노화에 따른 동맥 팽 창성(distensibility)의 감소뿐만 아니라 대사증후군에 의해 나타나는 인슐린 저항성은 동맥벽의 구조적·기능적 변화 를 촉진하여 맥압의 증가를 유도한다(Kwon et al., 2017). 또한 대사증후군에서 교감신경계의 활성화는 심박수, 좌 심실 수축력 및 전신 혈관 저항에 영향을 주어 동맥 팽창 성을 악화시킨다(Hall et al., 2001). 반면, 만성 저강도 염증 상태는 맥압과 대사증후군간의 관계를 매개하는데, 그 원 인으로 대사증후군은 지방조직에서 방출하는 친염증성 사 이토카인의 증가를 유도하여 염증 발현을 유발하기 때문 이다(Cooke et al., 2016). 이는 혈관내피기능 장애를 일으키 고 동맥 탄성을 변화시켜 동맥경화 및 맥압의 증가로 이 어질 수 있다(Kwon et al., 2017).

본 연구에서는 수축기와 이완기 혈압, 총콜레스테롤, 중 성지방, 공복혈당, 복부비만이 맥압과 양의 상관관계를 보 였으며, 복부비만, 높은 혈압, 높은 혈당과 고중성지방혈 증의 위험요인이 있는 경우 위험요인이 없는군보다 맥압 이 높았다. 이상지질혈증과 공복혈당은 맥압을 증가시켜 혈관 경직도에 영향을 줄 수 있는 위험인자로 보고되며 (Chae et al., 1999; Park et al., 2014), 당뇨, 고혈압, 고지혈증 은 동맥 경직도를 증가시키는 것으로 보고된다 $(\mathrm{Li}$ et al., 2011). 따라서 고지혈증이나 당뇨 등 대사증후군 위험요
인에 대한 적극적인 치료가 필요하겠다.

본 연구는 경기지역 일개 종합병원에서 건강검진을 실 시한 중년남성을 대상으로 하여 지역적, 연령, 성별에 대 한 확대해석에 제한이 있다. 또한 횡단면 연구로 결과해 석에 있어서 인과관계를 밝힐 수 없으며, 향후 전향적 연 구가 요구된다. 동맥경화를 직접적으로 측정하는 맥파전 달속도(pulse wave velocity, PWV)와 경동맥과의 평가가 이 루어지지 않았으며, 혈압에 영향을 줄 수 있는 염분섭취 나 운동 유무를 평가하지 못한 제한점이 있다. 이러한 한 계에도 불구하고 본 연구결과 노인뿐 아니라 중년남성에 서도 맥압은 대사증후군 위험요인과 관련이 있는 것으로 나타났으며, 대사증후군으로 진단되지는 않지만 1 2개의 위험요인을 가진 대사증후군 전단계군에서도 맥압의 증가 를 보여 대사증후군으로 진행될 가능성이 높은 단계로 예 방을 위한 조기 진단의 중요성이 강조된다.

\section{CONFLICT OF INTEREST}

The authors have no conflicts of interest to disclose.

\section{REFERENCES}

Benetos A, Rudnichi A, Safar M, Guize L. Pulse pressure and cardiovascular mortality in normotensive and hypertensive subjects. Hypertension. 1998. 32: 560-564.

Chae CU, Pfeffer MA, Glynn RJ, Mitchell GF, Taylor JO, Hennekens $\mathrm{CH}$. Increased pulse pressure and risk of heart failure in the elderly. Journal of the American Medical Association. 1999. 281: 634-639.

Choi SY. The characteristics of electrocardiography findings in left ventricular remodeling patterns of hypertensive patients. Biomedical Science Letters. 2015. 21: 208-217.

Cooke AA, Connaughton RM, Lyons CL, McMorrow AM, Roche HM. Fatty acids and chronic low grade inflammation associated with obesity and the metabolic syndrome. European Journal of Pharmacology. 2016. 785: 207-214.

Cremer A, Lainé M, Papaioannou G, Yeim S, Gosse P. Increased arterial stiffness is an independent predictor of atrial fibrillation in hypertensive patients. Journal of Hypertension. 2015. 33: 2150-2155.

Finkel T, Holbrook NJ. Oxidants, oxidative stress and the biology of ageing. Nature. 2000. 408: 239-247.

Franklin SS, Khan SA, Wong ND, Larson MG, Levy D. Is pulse pressure useful in predicting risk for coronary heart disease? The Framingham heart study. Circulation. 1999. 100: 354-360. 
Gasowski J, Fagard RH, Staessen JA, Grodzicki T, Pocock S, Boutitie F, Gueyffier F, Boissel JP; INDANA Project Collaborators. Pulsatile blood pressure component as predictor of mortality in hypertension: a meta-analysis of clinical trial control groups. Journal of Hypertension. 2002. 20: 145-151.

Grundy SM, Cleeman JI, Daniels SR, Donato KA, Eckel RH, Franklin BA, Gordon DJ, Krauss RM, Savage PJ, Smith SC Jr, Spertus JA, Costa F; American Heart Association; National Heart, Lung, and Blood Institute. Diagnosis and management of the metabolic syndrome: an American Heart Association/ National Heart, Lung, and Blood Institute Scientific Statement. Circulation. 2005. 112: 2735-2752.

Haider AW, Larson MG, Franklin SS, Levy D; Framingham Heart Study. Systolic blood pressure, diastolic blood pressure, and pulse pressure as predictors of risk for congestive heart failure in the Framingham Heart Study. Annals of Internal Medicine. 2003. 138: 10-16.

Hall JE, Hildebrandt DA, Kuo J. Obesity hypertension: role of leptin and sympathetic nervous system. American Journal of Hypertension. 2001. 14: 103-115.

Hildrum B, Mykletun A, Hole T, Midthjell K, Dahl AA. Agespecific prevalence of the metabolic syndrome defined by the International Diabetes Federation and the National Cholesterol Education Program: the Norwegian HUNT 2 study. BioMed Central Public Health. 2007. 7: 220.

Kim YM, Hong KS, Choi YH, Choi MG, Jeong JY, Lee JM, Kim $\mathrm{DH}$. Rates and related factors of progression to hypertension among prehypertensive local residents aged 45 or over in Chuncheon City: Hallym Aging Study from a CommunityBased Cross-Sectional Study. Korean Circulation Journal. 2008. 38: 43-50.

Kwon YJ, Chung TH, Shim JY, Lee YJ. The association of pulse pressure with metabolic syndrome in Korean elderly: A nationwide population-based study. Diabetes Research and Clinical Practice. 2017. 123: 75-81.

Lee JW. Pulse pressure and systolic blood pressure. Korean Circulation Journal. 2002. 32: 293-298.

Li CI, Kardia SL, Liu CS, Lin WY, Lin CH, Lee YD, Sung FC, Li TC, Lin CC. Metabolic syndrome is associated with change in subclinical arterial stiffness: a community-based Taichung community health study. BioMed Central Public Health. 2011. 11: 808 .

Mannucci E, Monami M, Bardini G, Sposato I, Ungar A, Pepe G, Masotti G, Marchionni N, Rotella CM. Metabolic syndrome and pulse pressure. Diabetes, Obesity and Metabolism. 2007. 9: 600-602.
Moon HK, Kong JE. Assessment of nutrient intake for middle aged with and without metabolic syndrome using 2005 and 2007 Korean National Health and Nutrition Survey. Journal of Nutrition and Health. 2010. 43: 69-78.

Moon K, Sung SH, Chang YK, Park IK, Paek YM, Kim SG, Choi TI, Jin YW. The association between Apolipoprotein E genotype and lipid profiles in healthy woman workers. Journal of Preventive Medicine \& Public Health. 2010. 43: 213-221.

Mulè G, Nardi E, Cottone $\mathrm{S}$, Cusimano $\mathrm{P}$, Incalcaterra F, Palermo A, Giandalia ME, Mezzatesta G, Andronico G, Cerasola G. Relationship of metabolic syndrome with pulse pressure in patients with essential hypertension. American Journal of Hypertension. 2007. 20: 197-203.

Pannier B, Brunel P, el Aroussy W, Lacolley P, Safar ME. Pulse pressure and echocardiographic findings in essential hypertension. Journal of Hypertension. 1989. 7: 127-132.

Park SY, Yoon H, Oh HJ. The association of metabolic syndrome, metabolic syndrome score and pulse pressure in Korean adults: Korea National Health and Nutrition Survey, 2012. Journal of the Korea Academia-Industrial Cooperation Society. 2014 9: 5660-5667.

Protogerou AD, Blacher J, Mavrikakis M, Lekakis J, Safar ME. Increased pulse pressure amplification in treated hypertensive subjects with metabolic syndrome. American Journal of Hypertension. 2007. 20: 127-133.

Scuteri A, Najjar SS, Muller DC, Andres R, Hougaku H, Metter EJ, Lakatta EG. Metabolic syndrome amplifies the age-associated increases in vascular thickness and stiffness. Journal of the American College of Cardiology. 2004. 43: 1388-1395.

Scuteri A, Orru M, Morrell C, Piras MG, Taub D, Schlessinger D, Uda M, Lakatta EG. Independent and additive effects of cytokine patterns and the metabolic syndrome on arterial aging in the SardiNIA Study. Atherosclerosis. 2011. 215: 459-464.

Wagenseil JE, Mecham RP. Elastin in large artery stiffness and hypertension. Journal of Cardiovascular Translational Research. 2012. 5: 264-273.

World Health Organization Western Pacific Region, International Association for the Study of Obesity, and International Obesity Task Force. The Asian-Pacific perspective: redefining obesity and its treatment. 2000. 15-21.

http://dx.doi.org/10.15616/BSL.2017.23.2.73

Cite this article as: Shin KA. The Association of Pulse Pressure and Pre-Metabolic Syndrome in Korean Middle Aged Men. Biomedical Science Letters. 2017. 23: 73-79. 